\title{
artículos
}

\section{La belleza satánica: el diablo melancólico}

Alexis Navas Fernández

Investigador vinculado a la UMA

PALABRAS CLAVE: Iconografía del Diablo/ Literatura Demonológica

\section{RESUMEN}

La figura del diablo en la cultura occidental tiene su origen en los escritos del pueblo judío. El ángel exterminador y los querubines son iconografías que se resisten a esta resistencia. Los Evangelios apócrifos a partir del 300 a.e. son una fuente fundamental para el estudio de la iconografía del diablo. La Edad Moderna es una etapa de profusión de la literatura demonológica.

\section{ABASTRACT}

The image of the devil in the western culture has its origin in the writings by Jewish people. The exterminating angel and his cherubim are iconographies which resist this resistance. The apocryphal Gospels from 300 b.C. are a basic source to study the iconography of the devil. The Modern Age is a stage of abundance of demonology literature.

GÉNESIS DE UNA IMAGEN, PASANDO REVISTA A ALGUNOS DE SUS PRECEDENTES PLÁSTICOS.

Las ideas que se han desarrollado entorno a la figura del diablo en la cultura occidental tienen su origen en los escritos del pueblo judío y las influencias que estos recibieron de sus vecinos. Rodeados de una serie de religiones politeístas su voluntad de monoteísmo hace que se produzca un fuerte rechazo hacía la multiplicidad de principios espirituales pero no se puede hablar de una total resistencia a dichas influencias como podemos observar en "el ángel exterminador" cuyo origen en un antiguo rito nómada, o los querubes que tienen su origen en los toros alados mesopotámicos, que custodian templos y palacios 1 . Una de las principales influencias provienen de su toma de contacto con la civilización babilónica, la cual desarrolla lo que se ha venido a llamar como la Épica de la Creación en la que Bel-Meridach, en la que combate a Timat, el dragón del caos que amenaza con destruir el orden del uni- 
verso; dichos mitos y símbolos lo podemos ver reflejados en Leviatán el dragón en Isaías 27,1 Aquel día el Señor, con su espada dura, grande y fuerte, castigará a Leviatán, la serpiente huidiza, a Leviatán, la serpiente tortuosa; y matará al Dragón que hay en el mar2; los demonios asirios están representados con rostros de animales y garras y los genios buenos son los que llevan alas ${ }^{3}$. No puede olvidarse como también recibe las influencias del Zoroastrismo, en dicha religión desarrollada en la región de Persia basada en la antinomia o dialéctica perpetua entre dos fuerzas opuestas Ahura Mazda u Ormazd, el bien, y su hermano gemelo Ahrimán cuya esencia es el mal y la mentira y que fue expulsado del cielo y arrojado al infierno ${ }^{4}$. Sin embargo debe tenerse en cuenta que en el Antiguo Testamento el diablo no pasa de ser una figura de carácter marginal, y va ha ser a partir del 300 a. de C. cuando va ha experimentar un gran auge debido a las leyendas que recogen los apócrifos ${ }^{5}$.

Una de las principales fuentes para el posterior desarrollo de la imagen del mal la van a constituir los escritos apócrifos. En el Libro de Enoc, escrito en torno al 200 a. de C., se relata cómo un grupo de ángeles abandonan el cielo, convirtiéndose en "malos", para unirse a las "hijas de los hombres", dando lugar a la raza de los gigantes, introductores del pecado en la tierra, que posteriormente son destruidos por el diluvio, siendo dichos ángeles encadenados. Este relato está relacionado con el Génesis 66; enlazando también con la gigantomaquia y el diluvio como castigo por la rebelión de la mitología greco-romana ${ }^{7}$. Otra variante de la historia de la entrada del pecado la encontramos a través de las enseñanzas de Asa'el de los secretos del cielo a los hombres ${ }^{8}$. Dicha historia remite, en cierta forma, con el pecado de trasgresión cometido por Prometeo al entregar el fuego a los hombres, por cuanto hasta ese momento era un elemento exclusivamente divino, y enseñando al hombre a utilizarlo. En el Libro de los Secretos de Enoc, escrito a principios de la Era Cristiana probablemente en Egipto, se narra el viaje de Enoc por las cortes celestiales y donde el Ser Supremo le narra la historia de Satanael, que pertenece al rango de los arcángeles, y sus seguidores el cual había pretendido equipararse a nivel del Señor y es expulsado del cielo. Otro tanto acaece en el Libro de los doce patriarcas en el que

1JIMENEZ, J.: El ángel caído. La imagen artística del ángel en el mundo contemporáneo, Barcelona, Anagrama, 1982, págs. 164-165.

2 O'GRADY, J.: El príncipe de las tinieblas. El demonio en la historia, la religión y la psique humana, Madrid, Edaf, 1990, págs. 16-17.

3 RISCO, V.: Satanás. Historia del diablo, Vigo, Nigratrea, 2003, pág. 89

4 O'GRADY, J.: Op. Cit., págs. 17-18.

5 JIMENEZ, J.: Op. Cit., pág. 166.

6 O'GRADY, J.: Op. Cit., pág. 20

7 OVIDIO.: Metamorfósis (edición de José Antonio Enríquez y Ely Leonetti Jungl), Cátedra, Madrid, 1994 págs. 79 y ss.

8 www.deliriumsrealm.com/delirium/religion/judaism enoch.asp. 
Belial compite con Dios por la supremacía sobre los hombres. ${ }^{9}$ Estas figuras nacen en un principio como espíritus mediadores entre el Ser Supremo y el hombre; siendo las alas la expresión plástica de dicha mediación; cuyos orígenes evocan los toros alados guardianes de templos mesopotámicos. Pero no sólo en estas figuras de mediación, sino también en otras pertenecientes a la cultura grecolatina como Icaro, Hermes o Eros se detectan analogías iconográficas, siendo estos dos últimos los portadores de la imagen asexuada que pasara al cristianismo ${ }^{10}$. La figura de Satán que en un principio tiene el significado de "adversario" se inviste de un sentido jurídico como "acusador" en el Antiguo Testamento, encontrándolo en el Nuevo Testamento enteramente personalizado, al hacerse explicita su naturaleza angélica según se puede observar en el Evangelio de Mateo $(25,41)$ y en el Apocalipsis $(12,7)^{11}$

Si seguimos a Haag, la teología católica al no poder admitir un principio negativo en la creación divina, recurre a la leyenda de la rebelión y caída de los ánge$l_{\text {les }}{ }^{12}$. A su vez fue influenciada durante los primeros siglos del cristianismo por diversos movimientos religiosos cristiano coetáneos como el Gnosticismo y el maniqueísmo lo cual derivaría en un cierto dualismo que va a subsistir durante la Edad Media13

Debido al problema que representaba su ambigüedad de ángel, pero caído, para su representación plástica, durante los primeros siglos del cristianismo las connotaciones negativas venían expresadas por su color oscuro; tal como podemos observar en San Apolinar Nuevo en Rávena; incluso podemos encontrar en el arte carolingio, en el Sacramentario de Drogo, un diablo humanizado inscrito en una D ${ }^{14}$. En el mosaico (s. VI) conservado en San Apolinar Nuevo en Rávena [1], donde se hacer referencia al Juicio Final el diablo no se diferencia en nada del ángel salvo por el color, lo cual viene a ilustrar el evangelio de Mateo... "pondrá las ovejas a su derecha y los cabritos a su izquierda, aquí el color rojo representa la luz y el azul las tinieblas"15.

Los problemas para fijar su representación visual derivan de la falta de descripciones físicas tanto en el Antiguo como en el Nuevo Testamento siendo las únicas las descripciones del dragón en el Apocalipsis que posteriormente derivarian en representaciones espantosas ${ }^{16}$ aunque se seguirá representando durante los siglos

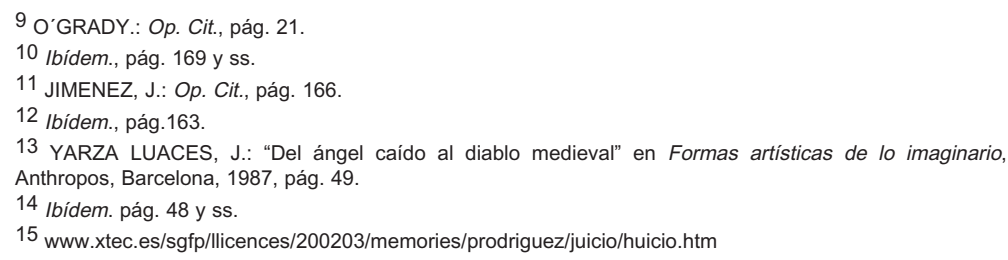




Q: artículos Alexis Navas Fernández

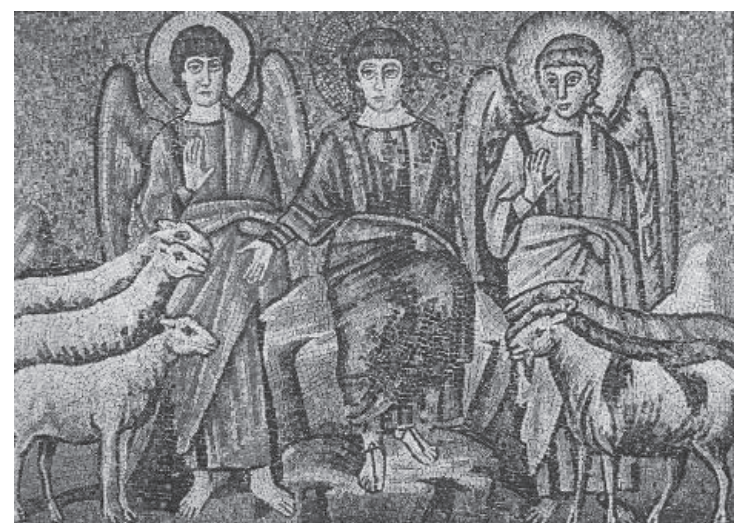

1. San Apolinar Nuevo en Rávena.

IX y X con muchas connotaciones que derivan de lo angélico ${ }^{17}$. A este respecto no debemos dejar de tener en cuenta que entre las habilidades del diablo se encuentra la de poder transformarse en una imagen agradable y atractiva para engañar y seducir al hombre, como podemos ver en 2 Corintios 11:14 Y nada tiene de extraño: que el mismo Satanás se disfraza de ángel de luz. Por otro lado, como posible origen de la imagen de fealdad atribuida al diablo, nos encontramos con la tradición del pequeño etíope sumada a los textos que hablan de seres negros como representantes de las tinieblas y los diablos burlones da lugar a la imagen del diablo bizantino que conectaría con las formas siniestras que se desarrollan en el románico ${ }^{18}$. Para comprender mejor este desarrollo evolutivo hacía una imagen grotesca, fea y terrorífica hay que tener en cuenta que para los primeros cristianos los dioses paganos eran siervos del diablo ${ }^{19}$. Esto unido con el símil aparecido en el Nuevo Testamento en el que se identifica al macho cabrío con los infieles, así como el desarrollo que en estos primeros momentos del cristianismo experimenta la dualidad entre espíritu y materia hacen que se identifique la sexualidad como algo diabólico, siendo por ello la figura mitológica de Pan representante de la fuerza de la destrucción y la creación pero

16 O'GRADY, J.: Op. Cit., pág. 55.

17 YARZA LUACES, J.: Op. Cit., pág. 53.

18 Ibídem., pág. 53.

19 O'GRADY, J.: Op. Cit., pág. 58. 
sobre todo del deseo sexual, acompañante del séquito de Dionisios y participante de sus orgías alcohólicas y de desenfreno sexual; todo lo cual no extraña que terminase deviniendo a que se le identificase con el diablo20.

Va a ser en la Edad Media donde la praxis artística se decante hacía una imagen "terrible" del Príncipe de las Tinieblas; aunque no va a estar exenta de manifestaciones que se alejen de dicha corriente dominante como podemos observar en la imagen descrita por Gonzalo de Berceo en los Milagros de Nuestra Señora en El romero de Santiago, en el que adopta la forma de un ángel para engañar al protagonista de la historia, no siendo ésta su forma verdadera21; también aparece Satán como Jano bifronte, un tipo icnográfico que del sentido positivo que tenía en la antigüedad pasa a negativo en la Biblia de León, libro de Job, San Isidoro de León. Esta interpretación icnográfica, posee ropajes oscuros pero rostro y manos del color usual de la carne, lo cual, a pesar de todo, no impide que siga siendo inherente a su representación cierto carácter monstruoso, dado por la bifrontalidad y ¡como! no por el color negro de los ropajes y en las alas ${ }^{22}$. Conserva las alas por cuanto antes había sido un ángel, pero ahora estas se han transformado en un elemento siniestro de su imagen dando lugar finalmente a unas alas de murciélago ${ }^{23}$; a esto hay que añadir la creencia desarrollada por Atenágoras desde el siglo II de que se trata de espíritus que rondan el aire y la tierra pero que no pueden remontarse hacía lo supraceleste 24 , lo cual explicaría, así mismo, la inclusión de las alas en este personaje.

La literatura en torno a la demonológica va a sufrir un fuerte impulso al inicio de la Edad Moderna debido a la crisis religiosa. En todas estas obras se mantiene una imagen de lo satánico vinculado a la fealdad, pudiendo señalarse el inicio de esta corriente con el Malleus Maleficarum (1486) de Jakob Sprenger y Heinrich Institoris, libro de un enorme éxito con veintiocho ediciones en los siglos XV y XVI, a lo que seguiría un gran auge de esta literatura en el XVI con una prolífica serié de títulos entre los que podemos destacar Reprovación de las supersticiones (1530) de Pedro Ciruelo y el ampliamente difundido De la démonomanie des sorciers (1531) de Jean Bodin. Llegando al XVII, se produce una especialización en diversos temas como posesiones, vampiros, diablos familiares según se advierte en la obra de Jourdain Guibelet Discours philosofique (1603) dedicada a los demonios íncubos y súcubo 25 . Una obra particularmente interesante es la de Johann Wier De praestigiis daemonum (1585) en la que se incluye una sección denominada Pseudomonarchia

\footnotetext{
20 Ibídem. págs. 58 y 59.

21 JIMENEZ, J.: Op. Cit., pág. 34

22 YARZA LUACES, J.: Op. Cit., pág. 63.

23 O'GRADY.: Op. Cit., pág. 60.

24 JIMENEZ, J.: Op. Cit., pág. 175

25 RISCO, V.: Op. Cit., págs. 8 y 9
} 
daemonum la cual consiste en una lista de nombres de demonios con sus descripciones $^{26}$. Es en el siglo XVI en que aparece más claramente el vinculo entre el melancólico saturnino con las practicas demoníacas, aunque dichas conexiones ya aparecen sugeridas con anterioridad por Ibn Ezra y Abu Masar27. Lucas Cranach ve en la melancolía, y por influencia de las doctrinas de Lutero, la influencia de Satanás sobre los hombres 28 .

En virtud de lo referido, se infiere que no existe una total correspondencia con su imagen plástica a partir de ahora, comenzándose a desarrollar ya en esta época una literatura que lo ensalzará, destacando como lo podemos encontrar en la obra de John Milton o William Blake. Dicha popularidad sobre las acciones de los demonios en el mundo se ve reforzada por la doctrina oficial de la Iglesia católica, que establece el Concilio de Trento (1543-1563), siguiendo las doctrinas de Dionisio el Aeropagita, por cuanto y debido a la naturaleza superior de los demonios que en un tiempo fueron ángeles, Satán domina sobre los hombres y sólo mediante la aplicación de los méritos de Cristo al individuo, éste es elevado al orden sobrenatural y queda por tanto exento del poder del demonio aunque tendrá que sufrir sus tentaciones; pero no hay que olvidar que estos se encuentran bajo el gobierno de Dios y de lo que se ha denominado tolerancia permisiva de Dios ${ }^{29}$. Todo ello lo podemos observar anteriormente en el libro de Job, cuando le da a Satán libertad de acción sobre los bienes de Job, pero haciendo la excepción de que no ponga la mano en él $(\mathrm{Jb}, 1,6-12)^{30}$

Este último factor integraría la figura de Satán como un elemento más para mantener el orden establecido, como un elemento de justicia divina, de lo cual tenemos una gran profusión de ejemplos en la estampería de romances españoles del siglo XVIII como La ingratitud filial castigada o El blasfemo de Viterbo ${ }^{31}$.

Si bien existe una clara tendencia a representar al diablo como carente de toda belleza física, como hemos visto anteriormente y atendiendo a su naturaleza malvada, también lo podemos observar en distintas manifestaciones. Teniendo en cuenta su poder para transformarse al que hemos aludido anteriormente, aparece como un anciano en Cristo entre el bautista y Satán disfrazado como un hombre mayor 1507-1508 de Pietro Perugino. Una de las primeras representaciones de la belleza satánica la encontramos en La caída de Lucifer [2] (1554-1556) de Lorenzo

26 www.deliriumsrealm.com/delirium/mythology/demon wier.asp

27 KLIBANSKY, R., PANOFSKY, E., SAXL, F.: Saturno y la melancolía, Alianza, Madrid, 1991, pág. 362.

28 Ibídem, pág. 385.

29 O'GRADY.: Op. Cit., pág.122.

30 JIMÉNEZ, J.: Op. Cit., pág. 161.

31 PEREZ GUILLEM, I.V.: Sombras en el siglo de las luces, Ars Longa 4, Valencia, 1993, págs. 112 y ss. 


Q E atículos La belleza satánica: el diablo melancólico.
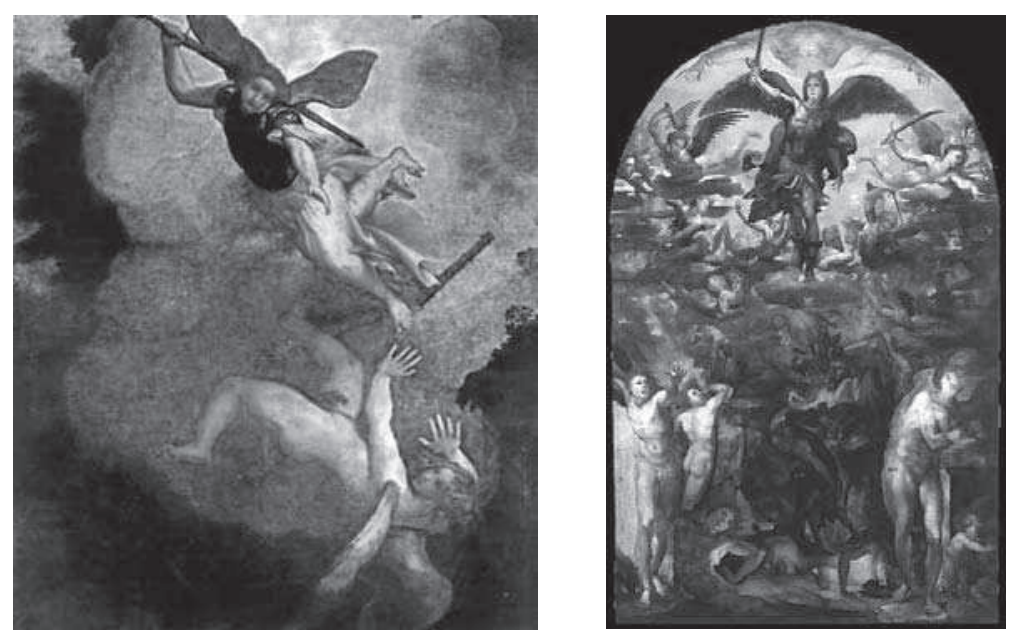

2. LORENZO LOTTO, La caída de Lucifer (1554-1556).

3. DoMENICO BECCAFUMI, Caída de los ángeles rebeldes (1540).

Lotto ${ }^{32}$, que observa el momento mismo de la caída, y donde el protagonista no ha visto minusvalorada todavía su naturaleza angélica. Con anterioridad, nos encontramos la representación de unos demonios que no han perdido su belleza angélica aún después de su caída, se trata de la obra de Domenico Beccafumi Caída de los ángeles rebeldes [3] (1540), realizada poco después del Juicio Final de Miguel Ángel y ante la cual se ha sugerido una posible influencia que se explicaría en la composición de los cuerpos de forma musculosa. Por otro lado, la confusión de la escena sugiere que la pintura no estuviese terminada ya que el artista no encontraría una solución satisfactoria para rematarla. ${ }^{33}$

También podemos observar la influencia de Miguel Ángel en la obra escultórica de Juan Martínez Montañés, en su Retablo mayor de la Iglesia de San Miguel de Jerez de la Frontera (1641) por la monumentalidad de su trabajo aquí desarrolla-

32 PRAZ, M.: La carne, la muerte y el diablo en la literatura romántica, El Acantilado, Barcelona, 1999, pág. 118.

33 www.galleryofart.com 


2: artículos Alexis Navas Fernández

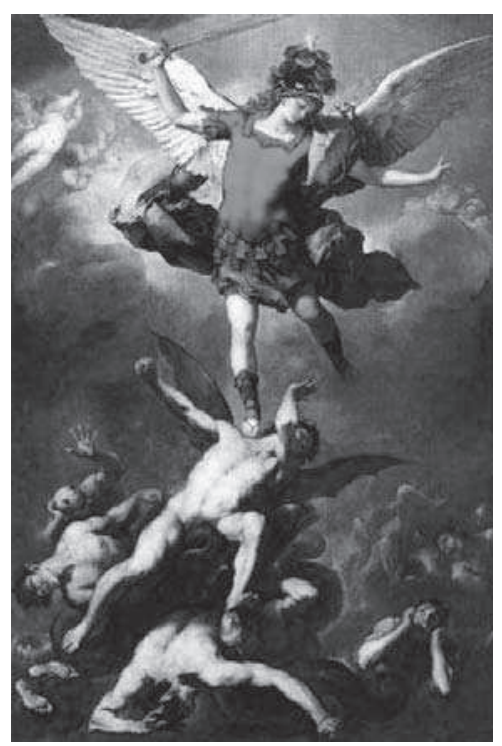

4. LuCA GIORDANO, La caída de los ángeles rebeldes (1666).

dística de luchar contra la herejía ${ }^{35}$. do, en la cual representa a un diablo de rasgos apolíneos y pletórico de sensualidad hedonista ${ }^{34}$.

A estas imágenes le siguen otras en que si bien se nos sigue mostrando a un Satán derrotado no ha perdido al menos totalmente su naturaleza angélica según podemos observar en la obra de Luca Giordano tanto en su Derrota de Luzbel como en La caída de los ángeles rebeldes [4] (1666) donde junto a la perfección anatómica de los cuerpos se puede observar cierto grado de fealdad que viene dada por las alas de murciélago y la cola de serpiente que se percibe entre la turbamulta entre los ángeles caídos; así como por los cuernos. A propósito de esta cuestión hay que recordar que en estos momentos la temática de la caída de los ángeles rebeldes cobra un nuevo impulso por medio de la Reforma católica, pues presentándose de esta forma la Iglesia exhibe una forma alegórica y propagan-

\section{SATAN: Rebelde, genio y meLANCólico.}

Una obra que ejercería una gran influencia posterior en la concepción de la imagen demoníaca será El paraíso Perdido (1667) de John Milton. El tema principal es la existencia del mal y el motivo de la desobediencia del hombre. Uno de los rasgos más destacados es el uso de la imaginación por parte de Milton, ya que las descripciones bíblicas son escasas; el uso de esta nos lleva a interpretar la mentalidad poética como más intuitiva que lógica, asimilándolo a un impulso en el que lo racional queda en un segundo orden. ${ }^{36}$ El concepto de imaginación entendido por los

34 HERNÁNDEZ DÍAZ, J.: Martínez Montañés, Sevilla, Guadalquivir, 1987, págs. 183 y ss.

35 www.galleyofart.com

36 MILTON, J.: El paraíso perdido, (edición de Esteban Pujals), Madrid, Cátedra,1986, págs. 21-22. 
empiristas ingleses del siglo XVIII como creación de mundos inexistentes va a pasar a interpretarse con el Romanticismo, como parte de la realidad intrínseca del individuo ${ }^{37}$, lo cual va a provocar, según nuestra hipótesis, que esta obra tenga tanta trascendencia en el Romanticismo. No sólo esto, sino interpretaciones singulares como la de Blake quién reconoce en Satán el héroe del poema, que acierta a plasmar en su serie El matrimonio del cielo y el infierno (1790-1793). No en balde, la exaltación romántica de la rebeldía y el desorden es visto por cierta parte de la crítica literaria como una interpretación errónea del poema38.

Parece ser que el hecho de que el Satán de Milton se distancie tanto de la figura teológica sería debido a que en él confluyen las ideas políticas del autor, las cuales se basaban en el rechazo a la tiranía y a la falta de libertad de pensamiento, lo cual convierte a la figura de Satán en el héroe trágico que suscita la simpatía y admiración del lector/espectador por su valentía ante Dios, el autócrata que aplasta cualquier signo de rebelión 39 . Por otro lado también podemos extraer de la figura poética de Satán los rasgos que lo humanizan, ya que en múltiples ocasiones se muestra más humano que el mismo hombre, con sus remordimientos, su orgullo incluso su compasión en ciertos momentos, lo que nos recuerda la doctrina de Arquígenes, dentro de la literatura fisiológica de la Antigüedad, a la hora de diagnosticar la melancolía entre cuyos síntomas se encuentran las transiciones bruscas de la hostilidad, la mezquindad y la avaricia a la sociabilidad y la generosidad40. Por otro lado encontramos elementos de pasión amorosa en la figura de Eva, incluso ciertas actitudes de nihilismo y duda de Adán: “¿Quién lo sabe, o quien sabe más que/somos polvo y al polvo volveremos, $/ Y$ ya no existiremos nunca más?"41 son lo que más nos interesan, aunque todo esto es expresado siempre bajo el prisma de la caída del hombre, que hace que pierda la gracia divina. Pero la auténtica victima del poema sería ese Dios sin trono que es el Caos que existe a la vez que Dios y Satán y al que ambos van recortando terreno. Cuando Eva proclama: "Le amo tanto, que con él podría/ soportar todas las muertes, y sin él/ no habrá vida que vivir pudiera"42. Esto es uno de los rasgos propios del enamorado romántico: la tragicidad del deseo de morir y la ambición de vivir que se entremezclan y que podremos observar en el Romanticismo en Hölderlin la muerte es mensajera de vida; en Keats cuando

37 BOZAL, V. (ed.): Historia de las ideas estéticas y de las teorias artísticas contemporaneas 1, Madrid, 2000 , Visor, pág. 261 .

38 MILTON, J.: Op. Cit., págs. 41-42.

39 O’GRADY, J.: Op. Cit. pág. 150

40 KLIBANSKY, R., PANOFSKY, E., SAXL, F.: Op. Cit., pág. 69.

41 MILTON, J.: Op. Cit., pág. 452.

42 Ibídem, pág. 384. 
en Fall of Hyperion presenta la función procreadora de la muerte en el nacimiento de Apolo43.

El Satanás de Milton, como expresión de energía heroica, no ha perdido todo su esplendor después de la caída y en él observamos rasgos de melancolía y de rebelde indómito como el Prometeo de Esquilo o el Capaneo de Dante, que, por otro lado, ya aparecen en el Satanás de Marino ${ }^{44}$. Este carácter de rebelde irreducible viene expresado por las palabras con las que se dirige a los líderes de los ejércitos rebeldes:

“....¿Qué importa si la batalla está perdida?

No está perdido todo; la voluntad inquebrantable

La preparación de la venganza, el odio inmortal

$Y$ el valor para no someterse nunca ni ceder:

¿Qué más hace falta para no ser vencido?" 45

El Satanás de Milton no sufre la melancolía como "enfermedad" sino como rasgo intelectual. Se asemeja a la figura de los héroes malditos -Ayax, Heracles, Belerofonte- que recoge el Problema XXX, 1 atribuido a Aristóteles en la medida que son castigados por una deidad superior. Existía en Grecia la creencia popular, que recoge Aristóteles en su Metafísica, ...la divinidad es por naturaleza celosa, entonces todos los hombres excepcionales (sobresalientes) por fuerza han de ser desdichados, aunque Aristóteles rechaza esta creencia ${ }^{46}$. La filosofía aristotélica une la idea clínica de la melancolía con la concepción platónica del furor dando lugar a la tesis de que todos los hombres sobresalientes eran melancólicos ${ }^{47}$, lo cual lo podemos observar en el Problema XXX, 1. El autor de dicho Problema trata de justificar y comprender cómo los hombres excepcionales, a partir del exceso tenían la fuerza para equilibrase 48 .

El carácter prometeico de la rebelión contra el orden establecido procede del drama de Esquilo Prometeo encadenado, al insistir en el impulso del hombre para asaltar el cielo y de esta forma convertirse en Dios. Dicho impulso lo encontramos desarrollado en el romanticismo alemán en la obra de Hólderlin Der Rehin y en Empedokles ${ }^{49}$. Del mismo modo, también lo encontramos en El matrimonio del Cielo y el Infierno de William Blake y que Swinburne denominó Holy Insurrection y que se

43 ARGULLOL, R.: Op. Cit., pág. 282.

44 PRAZ, M.: Op. Cit. págs. 117 y ss.

45 O'GRADY, J.: Op. Cit., pág. 152.

46 KLIBANSKY, R., PANOFSKY, E., SAXL, F.: Op. Cit., pág. 61

47 Ibídem, pág. 41

48 Ibídem, pág. 61

49 ARGULLOL, R.: Op. Cit., pág. 207. 

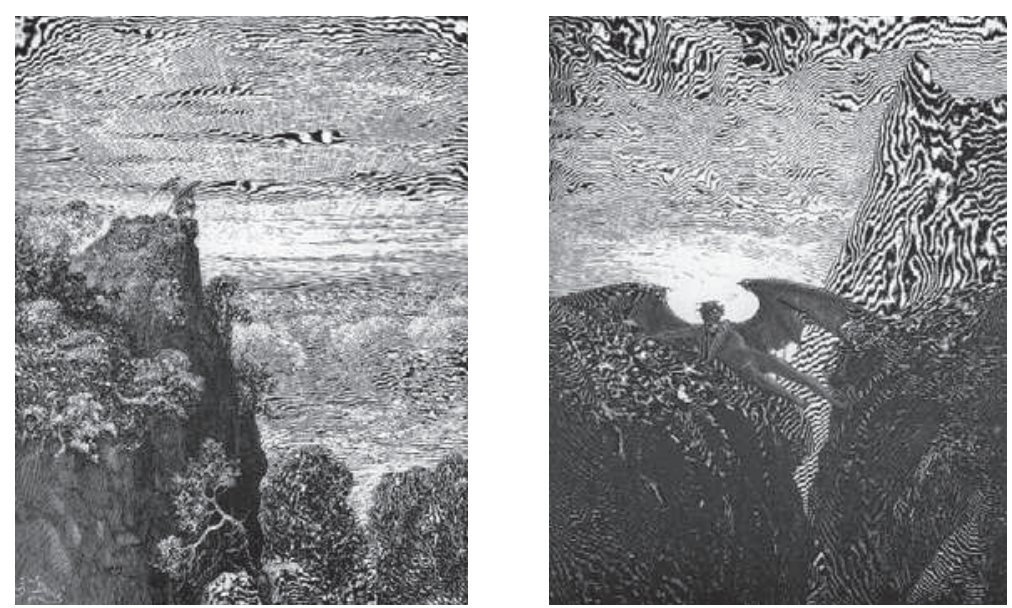

5. GUSTAVO DORÉ, Lucifer contempla el Paraíso.

6. GustaVo DORÉ, La melancolía de Lucifer.

trata de la rebelión del hombre contra Dios, gracias a la cual el hombre se transformará en Dios sobre la tierra 50 . El Satanás de Milton ante el fracaso de su intento sigue manteniendo su carácter de rebeldía: Aunque sea en el Infierno: mejor es/ reinar aquí que servir en el cielo 51 .

Se trata de un Satanás que no ha perdido totalmente su belleza Pues ni incluso los ángeles caídos/ toda su virtud pierden52. Esta imagen de Satanás melancólico aparece ya en el poema de Marino, pasando al Satanás de Milton en sus ojos centelleantes/que albergan melancolía y muerte ${ }^{53}$;(los ojos es una de las vías de salida de la bilis negra, causante del temperamento melancólico ${ }^{54}$ ) y a su vez la podemos observar en las ilustraciones que realizó Doré en donde aparece meditabundo: "iba pues pensativo y lentamente subiendo Satán [5], la noche entretanto empezó su curso, [6] al igual que en ¡Oh tierra! ¡Cuán semejante eres al cielo!” [7].

50 PRAZ, M.: Op. Cit., pág.. 417

51 MILTON, J.: Op. Cit., pág. 80.

52 MILTON, J.: Op. Cit., pág. 122.

53PRAZ, M.: Op. Cit., págs. 116 y ss.

54 KLIBANSKY, R., PANOFSKY, E., SAXL, F.: Op. Cit., pág. 78. 


Q: artículos Alexis Navas Fernández
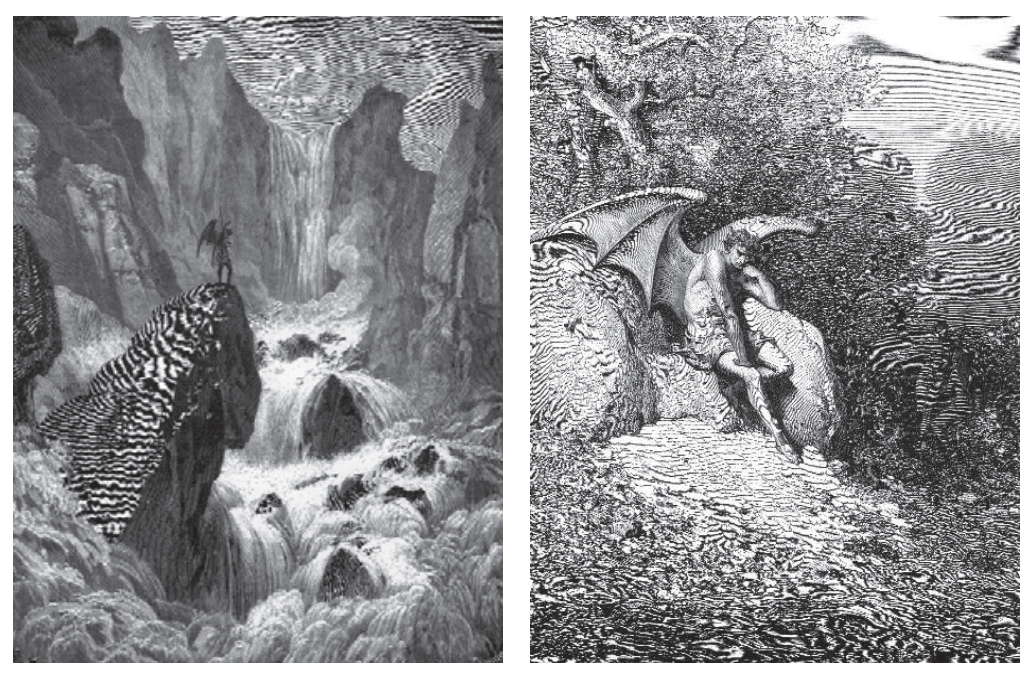

7. GuSTaVo DoRÉ, Lucifer frente al abismo.
8. GuSTaVo DoRÉ, Lucifer medita su venganza.

En estos dos últimos grabados se nos remite a la figura tradicional del diablo con cuernos a través del cabello hacía atrás encrespado y icómo no! por las alas de murciélago que serán el principal rasgo diferenciador de los ángeles, ya que ambos están representados anatómicamente perfectos.

Observamos en las ilustraciones de Gustavo Doré para El paraíso perdido de Milton la profusión del motivo de la mejilla apoyada en la mano, pues no solamente figura en la ilustración anteriormente citada, sino que también puede vislumbrarse en "Oh tierra! ¡Cuán semejante eres al cielo! Horrible fue la silba que se desató por todos los ámbitos del salón" [8]. Dicho motivo, que tradicionalmente ha estado vinculado a Saturno y al temperamento melancólico hunde sus raíces en la antigüedad apareciendo en los sarcófagos egipcios como motivo de dolor, pero también como fatiga o pensamiento creador, el sentido en que es utilizado por Durero en Melancolia I [9] como dolor, fatiga y meditación ${ }^{55}$. En este sentido podemos interpretar la ilustración de Doré ¡Oh Tierra!.. , meditación por los pensamientos que expresa en el poema para

55 Ibídem, págs. 281 y 282. 


Q - artículos La belleza satánica: el diablo melancólico.
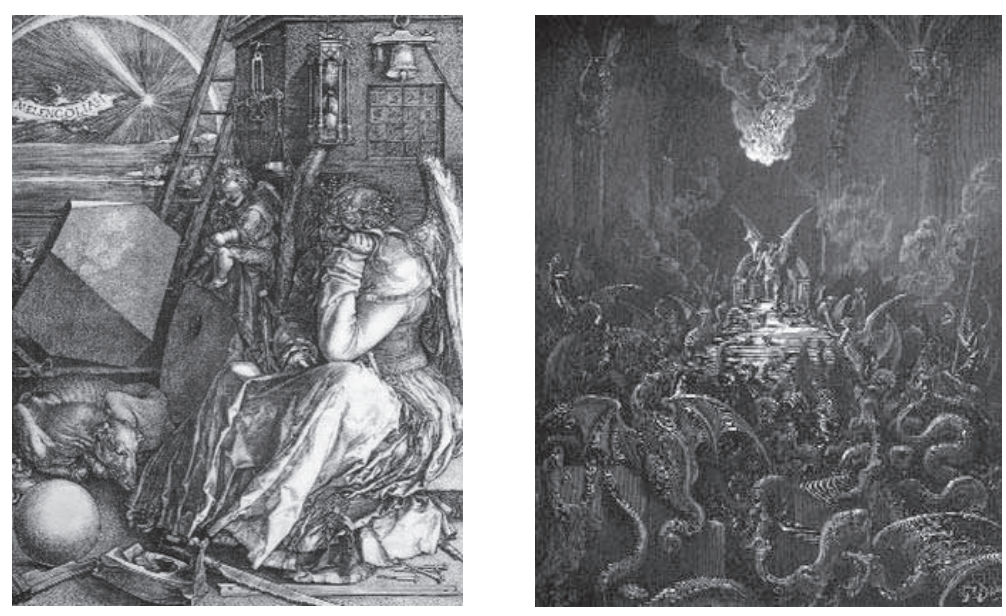

9. A. DuRERo, Melancolía.

10. GustaVo DORÉ, Horrible fue la silba.

la perdición del hombre, fatiga por el viaje que ha emprendido desde el infierno hasta el paraíso y el dolor que siente sería la envidia expresada hacía la benevolencia del Creador para con el hombre. También podemos observar la tríada desarrollada por Durero en La noche..., ya que el dolor vendría dado por la derrota ante los ángeles que se mantenían fieles a la voluntad divina, la fatiga por la batalla desarrollada la jornada anterior y en la que Satán experimento por primera vez el dolor y meditación por la preparación de los planes para la posterior jornada de enfrentamientos. En un sentido más vinculado con el Kronos mítico que se distinguía por la fisonomía de un anciano triste o pensativo56 aparece en Horrible fue... [10] en la que aparece en su trono del infierno con la mejilla apoyada en la mano como el Saturno del Sepulcro de Cornutus de los jardines del Vaticano. Debemos de tener en cuenta que un posible nexo de unión entre ambas figuras vendría dado por el hecho de que ambas sufren un "descenso" que en el caso de Saturno es enviado al Tártaro, que es el centro de la tierra por debajo del Infierno y que posteriormente se identificaría con el Infierno como tal ${ }^{57}$.

56 Ibidem, pág. 154.

57 OVIDIO: Op. Cit., pág. 79. 
El hecho de que en las ilustraciones anteriormente citadas la mano no se muestre suelta contra la mejilla sino cerrada como en el grabado de Durero anteriormente citado no sólo establece un precedente plástico para las ilustraciones de Doré, sino que denota una más que probable relación con el temperamento melancólico, ya que el puño cerrado se había considerado con anterioridad a Melancolía I como un rasgo de la avaricia típica del temperamento melancólico ${ }^{58}$. Dicho motivo tiene su origen en la Antigüedad, cuando Alejandro de Tralles al mencionar como síntoma de la melancolía un espasmo de los dedos probablemente una rigidez en el dedo corazón pero que, posteriormente, se interpretó como un cierre involuntario del puño59. También el puño cerrado realiza aquí la misma función que tenía para un ilustrador medieval como signo de desilusión, por la derrota de su rebelión en La noche... y en el mismo sentido que Durero encarna la concentración fanática de una mente que ha sido verdaderamente un problema, pero que en el mismo momento se siente tan incapaz de resolverlo como de desecharlo60.

Otro rasgo que aparece ampliamente desarrollado en los grabados de Doré al ilustrar la figura de Satán y que lo vincula con la tradición de lo melancólico y lo saturnino es el rostro oscuro, rasgo que aparece ampliamente desarrollado en los escritos medievales sobre Medicina, así como en los textos astrológicos sobre los planetas y los tratados populares sobre las cuatro complexiones61. Más adelante, se precisarán las connotaciones negativas que se han ido vinculadas al color negro.

Es evidente cómo en la obra poética de Milton la melancolía aparece como la facies nigra anteriormente descrita pero con el nombre de "Pensieroso", lo cual indica el posible conocimiento de la estatua de Lorenzo de Medicis realizada por Miguel Ángel, y de esta forma la acompaña de connotaciones positivas 62 . El carácter melancólico fue asociado al temperamento artístico hasta el siglo XVI, pasando de moda en el XVII, y retornando a la palestra en el XIX63. La definición generalmente aceptada para definir el carácter melancólico podemos rastrearla en la obra de Timothy Bright On Melancholy (1586)64:

“...frio y seco, de color negro y atezado, de una sustancia que se inclina hacia la dureza, enjuto de carnes..., tiene una memoria bastante buena si la fantasía no la borra; es firme en sus opiniones que difícilmente cambia una vez que

58 KLIBANSKY, R., PANOFSKY, E., SAXL, F.: Op. Cit., pág. 283.

59 Ibídem, pág. 75.

60 Ibídem, págs. 307 y 308

61 Ibídem, pág. 284

62 Ibídem, págs. 227 y 228.

63 WITTKOWER, R. y M.: Nacidos bajo el signo de Saturno, Madrid, Cátedra,1995, pág. 108.

64 Ibídem, págs. 106 y ss. 
Q artículos La belleza satánica: el diablo melancólico.

haya tomado una resolución; dudoso antes y tardo en su deliberación; suspicaz, arduo en sus estudios, y circunspecto, propenso a sueños espantosos, y terribles; en sus afectos, triste y lleno de miedo, es difícilmente incitado a la ira pero la guarda mucho tiempo y no se reconcilia fácilmente; envidioso y celoso, pronto a optar por la peor parte de los lances y desmesuradamente apasionado. De estas dos disposiciones del cerebro y del corazón surgen la soledad, los gemidos, las lágrimas...; los suspiros, los sollozos, la lamentación, una cara resignada y cabizbaja, sonrojada y tímida, de paso lento, silencioso, perezoso; rehúsa conocer y frecuentar a los hombres; se deleita en la soledad y la oscuridad".

Aquí vemos rasgos propios de la figura de Satán del poema de Milton como la firmeza en sus opiniones, su imposibilidad de reconciliación, la envidia y los celos. Y un rasgo que observamos en los grabados de Doré: la figura cabizbaja. Es también interesante comprobar cómo el color negro que aparece como rasgo de los melancólicos se asocia al error, la falsedad, la maldad y la negación de la luz que simboliza la divinidad aunque también puede ir asociado al grado que precede a la regeneración o el combate contra las fuerzas del mal65, pero no creemos que sea aquí el caso. Esta hibridación de los rasgos satánicos con el temperamento melancólico de los artistas, entendemos que es una forma de humanizar la figura satánica. Por otro lado no debemos olvidar la figura del artista-genio como alter Deus aparecido en el Renacimiento florentino, el artista genial no es Dios pero tampoco es un hombre común; está vinculado con los flujos del creador divino66, también lo podemos entender como competidor de éste al igual que el demonio. Dicho cambio vino dado por la conjunción de la idea neoplatónica, según la cual Saturno representaba y concedía al hombre las facultades más elevadas del alma que eran la razón y la especulación; y la doctrina aristotélica de la melancolía según la cual todos los hombres excepcionales la sufren ${ }^{67}$. A esto último se le unió la doctrina de Marsilio Ficino, donde se cementa la excepcionalidad del saturnino, con la identificación de la doctrina aristotélica de la melancolía con el furor divino de Platón. Debido a esto, los pensadores llegan a cuotas más altas del conocimiento y la comprensión, pero el cual esta sujeto a un destino en el cual su salud no sale bien parada68. Esta línea del ser excepcional inteligente es la que preside el poema de Milton y el que refleja las ilustraciones de Doré. Este sentimiento de ser excepcional es el que refleja Schiller en los

65 PORTAL, F.: El simbolismo de los colores, (José J. Olañeta Ed.), Barcelona, 2000, págs. 83 y ss. 66 ARGULLOL, R.: Op. Cit., pág. 295.

67 KLIBANSKY, R., PANOFSKY, E., SAXL, F.: Op. Cit., pág. 244.

68 Ibídem, pág. 254 y ss. 
Masnadieri (1781) ¿No era un genio extraordinario aquel ser que osó declarar la guerra al Omnipotente? Mejor es quemarse en el fuego de Belial en compañía de Borgia y Catalina que esta sentado a la mesa celeste con todos los imbéciles vulgares ${ }^{69}$. No esta de más recordar cómo Tomas de Aquino recoge en Summa Theologica que los ángeles como espíritus puros tienen su naturaleza volcada hacia el conocimiento, pero que aun siendo superior al del hombre es inferior al de Dios ${ }^{70}$.

Otros puntos en común que se encuentran asociados a los personajes de Satán y de Saturno como temperamento melancólico, pero que no aparecen relacionados en el poema de Milton ni en las ilustraciones de Doré, tendrían que ver con las connotaciones negativas de ambos, en la medida que se los retrata como devoradores de niños, Saturno a sus propios hijos y de las leyendas que hablan de sacrificios de niños en los rituales satánicos. Por otro lado la figura del dragón, a cuyo origen mesopotámico ya hemos aludido al principio, ha venido identificándose como una de las representaciones plásticas de la imagen del demonio encontrandose así descrito en el Apocalipsis $(12,9)$ Y fue arrojado el gran Dragón, la Serpiente antigua, el llamado Diablo y Satanás, según se ve en numerosas representaciones plásticas del diablo como aparece en El combate de San Miguel y el dragón diablo en Mont-Saint Michel. En Las muy ricas horas del Duque de Berry (s. XV) observamos cómo el dragón aparece asociada a Saturno, tirando del carro que lo transporta a través del firmamento en Saturno y sus hijos (s. XV), se trataría de "Dragones del Tiempo" que se muerden la cola ${ }^{71}$. Debido a la asimilación que se produce entre Kronos- Saturno, la hoz aparece como atributo vinculado a este último; figurando ésta también como un elemento asociado al diablo en las tentaciones de San Abraham, en las que se relata que demonios armados de hoces invadían la cabaña72.

También resulta interesante observar la relación existente entre las creencias en las posesiones diabólicas y la melancolía; la confusión entre ambas debió ser un hecho frecuente si atendemos a las disposiciones emitidas al respecto por el Sínodo de Reims en 1583, que declaran como un exorcista debe investigar todos los aspectos de la vida del paciente, ya que en ocasiones, los crédulos y los melancólicos tenían más necesidad de un médico que de un exorcista73.

Otras ilustraciones sobre el poema de Milton representan a un Satán con gran perfección anatómica, siendo la principal diferencia entre ellos el diferente tratamiento que realizan del tema de las alas. Aunque la mayor parte de ellos represen-

69 RISCO, V.: Op. Cit., pág.10.

70 JIMÉNEZ, J.: Op. Cit., pág.177.

71 KLIBANSKY, R., PANOFSKY, E., SAXL, F.: Op. Cit., pág. 208.

72 RISCO, V.: Op. Cit., pág. 196

73 O'GRADY.: Op. Cit., pág. 142. 
tan a Satán con las alas emplumadas, rasgo que lo asemeja a los ángeles convencionales, otros como Fuseli o Blake lo pintan sin alas, aunque este último tiene gran número de ilustraciones en las que aparece con las alas coriáceas del murciélago al igual que en John Martin. Dicho motivo tiene su origen en Oriente pasando posteriormente a Europa y haciéndose cada vez más frecuente en las representaciones del diablo a partir del siglo XIII74.

Un rasgo que nos ha llamado la atención ha sido el mantenimiento de las connotaciones negativas a través del casco que realiza Edward Burney, teniendo uno de sus antecedentes en los cascos medievales como el que utiliza Jaime de Aragón con cabeza de dragón y alas que data de la segunda mitad del siglo XIII75

LA IMAgen de SATÁN EN EL SIgLo XIX.

A lo largo del siglo XIX se produce un nuevo auge de la melancolía a la par que el de la imagen "positiva" del diablo. Para los románticos, la melancolía tiene una esencia "ilimitada" en el sentido de lo inconmensurable como de lo indefinible, dejando de lado los tópicos que la acompañaban como refleja Keats en su Oda a la melancolía ${ }^{76}$. Así se produce una reinterpretación del grabado de Durero como retrato directo de un personaje fáustico ${ }^{77}$, este hecho lo debemos de entender como parte del proceso de rehabilitación de la figura del demonio a lo largo del siglo y que, como ya hemos visto, tiene un arranque mucho anterior.

A continuación realizaremos un breve bosquejo de los distintos enfoques que tiene la imagen del diablo a lo largo del siglo. Existe una corriente desarrollada a partir de Byron y Shelley, que contemplan a Satán y a sus seguidores con el encanto de aquellos que luchan por la libertad y se arriesgan ${ }^{78}$. Esta misma línea de elogios hacia la fígura de Satán la podemos encontrar en Baudelaire en sus Letanías a Satán, al igual también lo podemos ver reflejado en el Inno a Satana (1863) de Giosuè Carducci, en el que Satán es el símbolo de la libertad, la ciencia y el progreso ${ }^{79}$. Observamos, pues, como se encuentra plenamente configurada la imagen de Satán en calidad del prototipo de héroe que lucha contra el poder establecido en los escritos de Proudhon:

74 BALTRUSAITIS, J.: La Edad Media fantástica, Cátedra, Madrid, 1983, pág. 153 y ss

75 Ibídem, pág. 158

76 KLIBANSKY, R., PANOFSKY, E., SAXL, F.: Op. Cit. págs 235 y 236.

77 Ibídem, pág. 348.

78 O'GRADY.: Op. Cit., pág. 153

79 RISCO, V.: Op. Cit. pág. 10. 
"Ven, Satanás, calumniado por los sacerdotes y los reyes, que yo te beso, que yo te abrazo contra mi pecho....Tus obras, joh, bendito de mi corazón!, no son siempre bellas y buenas, pero sólo ellas dan sentido al universo, le impiden ser absurdo. Tú solo animas y fecundas el trabajo, tú ennobleces la riqueza... Espera todavía joh proscrito!"80

Otra vertiente de la imagen satánica, que recoge gran parte de la carga negativa tradicional, puede rastrearse en el personaje de Heathcliff en Cumbres Borrascosas. A través de las descripciones que del mismo realiza Nely Dean, cuyas constantes comparaciones entre Heathcliff y Satanás contribuyen a situar el personaje en un trasfondo de tipología cristiana ${ }^{81}$.Tales comparaciones resucitan en boca de otros personajes como la señora Linton, un chico endemoniado, en cualquier caso ${ }^{82}$. Aunque no todas las descripciones de Nelly son peyorativas, cuando regresa tras sus años de ausencia en una primera mirada lo que ve es "...una alta silueta de un hombre vestido con ropas oscuras, como asimismo eran también oscuros su pelo y su tez"83. La oscuridad que domina la figura de Heathcliff es el reflejo de su personalidad, asociada como hemos visto, al demonio. Secularmente el color negro es uno de los símbolos del demonio por cuanto el negro es la negación de la luz símbolo divino ${ }^{84}$. Queda patente a lo largo de todo el relato la falta de moderación del personaje, lo cual lo asimila en cierto modo al modelo enunciado por el Problema XXX 1, al hombre excepcional vinculado al temperamento melancólico.

Desde un punto de vista distinto es como trata el tema Rimbaud en Una temporada en el Infierno (1873), en la cual no procede a una invocación a la manera romántica, sino que se trata de un descenso a los infiernos en la búsqueda de la "iluminación" del poeta, en la que rechaza de pleno el cristianismo y toda la tradición cultural occidental y busca la "iluminación" en lo no occidental ${ }^{85}$. Otra perspectiva sobre el tema lleva a Victor Hugo a anunciar, en 1886, La fin de Satán; el mal, que no es más que un vehículo para explicar la imperfección de la sociedad humana, no existe $^{86}$. La imagen de Satanás, arquetipo de rebelde contra el orden establecido no es exclusiva de las artes, en La bruja (1862) de Jules Michelet que defiende la existencia de los brujos lo ve de esta forma a la vez que como un dios natural que hace brotar las plantas 87 .

80 PROUDHON.: De la justice dans la Révolution et dans I'Eglise,Ill, 1870 , 240,en RISCO, V.: Op. Cit., pág. 332

81 BRONTE, E.: Cumbres Borrascosas, Madrid, Cátedra,1993, pág. 89.

82 BRONTE, E.: Ibídem., Barcelona, Alba Editorial, 2001, pág. 81.

83 Ibídem, pág. 146.

84 PORTAL, F.: Op. Cit., pág. 83.

85 JIMENEZ, J.: Op. Cit., pág. 119

86 RISCO, V.: Op. Cit., pág. 10 
No obstante, el demonio que retrata Ary Scheffer en su Tentación de Cristo (1854) no esta exento de belleza aunque no parece haber sido conservado sino para hacer resaltar el triunfo de la figura humana pura, representada por Cristo, sobre la forma híbrida del ser mitológico ${ }^{88}$, lo cual nos remite a una de las definiciones de la fealdad, relativa en relación con la belleza descrita por Karl Rosenkrantz en su Estética de lo Feo (1853). Dicho grado de fealdad vendría dado por el mantenimiento de las alas de murciélago y la oscuridad de su cuerpo en relación con el de la figura de Cristo. Por otro lado Cabanell transmite una impresionante hermosura, cuyo concepto la maldad de la figura tan solo viene sugerida por la mirada. A este respecto debemos recordar la importancia de la mirada en el Satán de Marino y vía de escape de la melancolía por los ojos.

Siguiendo el recorrido a través de la imagen plástica del Satán decimonónico, un grado notable de exégesis heroica se manifiesta en la obra escultórica más conocida de Bellver El ángel caído (1878); la cual, siguiendo la corriente de la época, nos muestra a un Satán pleno de belleza. Al igual que al Laocoonte se le enrosca la serpiente en el cuerpo y su composición lineal y la línea abierta nos remiten al barroco berniniano 89 . El momento que representa sería el de la expulsión del paraíso, la serpiente enroscada aludiría a la tentación y las cabezas de dragón que se encuentran en la base representan las fuerzas de las profundidades que hay que vencer para escapar del infierno90. Imagen que por otro lado habría "recuperado" la plenitud de su naturaleza angélica, lo cual vendría por medio de las alas que son iguales a las de los ángeles, según veíamos en San Apolinar Nuevo De forma bien distinta trata el mismo asunto Aguste Rodín con una obra del mismo titulo; su Ángel caído (1895) en el cual la masa del cuerpo quebrado confunde las partes en una violenta torsión, a la vez que tiene mucho de humano, ya que se asemeja al mito de Ícaro y que vendría a representar el vuelo vano de nuestras ilusiones ${ }^{91}$

A medio camino entre la belleza y la fealdad, como un híbrido mitad animal y mitad humano, nos lo muestra J. Delville en Los tesoros de Satán [11] (1894). En dicha obra los pecadores, se precipitan en un torrente de cuerpos entrelazados, atrapados por los bienes materiales y la sensualidad encontrándose de esta forma a un nivel bajo de la evolución espiritual; siendo atrapados por un Satán bello, lo cual revela su naturaleza espiritual, como ser bajo de quien surgen los tentáculos para capturar a los pecadores ${ }^{92}$. Volviendo hacia una la imagen más grotesca del diablo

\footnotetext{
87 Ibídem, pág. 11.

88 HELLO, E.: Phylosophie et Atheisme, París, Perrin,1906 págs. 200 y s., en RISCO, V.: Op. Cit., pág. 331

89 MARTIN GONZALEZ, J.J.: Historia de la escultura, Madrid, Gredos, 1970, pág. 299.

90 G. MOREDA, E.: "Fuente del ángel caído", El Mundo, 22 Agosto 2003.

91 JIMÉNEZ, J.: Op. Cit., págs. 121 ss.

92 www.bc.edu/bc_org/avp/cas/fnart/art/delville.html
} 


Q: artículos Alexis Navas Fernández

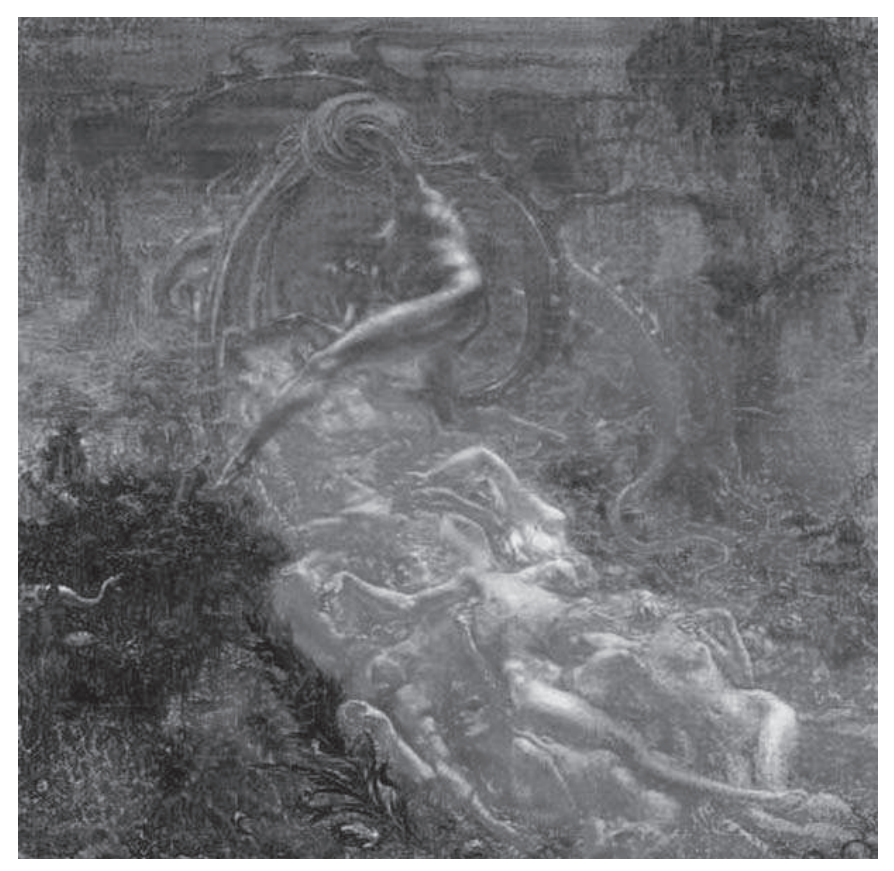

11. J. DELVILLE, Los tesoros de Satán.

tenemos la obra de Jean-Jacques Feuchère, esto es su Satán (21) (1836) recoge diversas influencias: toma la pose de Melencolia I de Durero, el rostro de una de las gárgolas que se encuentran en Notre Dame y el cuerpo de la ilustración de Delacroix para el Fausto de Goethe Mefistófeles en el aire ${ }^{93}$. Aunque a modo de conclusión podemos afirmar que la imagen que va a prevalecer es la de la belleza satánica.

93 www.artcyclopedia.com/artists/feuchere jean-jacques.html 